\title{
Effectiveness of Intervention Program on Cognition and Academic Achievement of 7-16 year old Students - A Longitudinal Study
}

\author{
Shruti Marwaha ${ }^{1} \& A$. K. Sinha ${ }^{2} \&$ Ramesh Sahani ${ }^{3}$ \\ ${ }^{1,2 \& 3}$ Department of Anthropology, Panjab University, Chandigarh, India \\ Correspondence: Shruti Marwaha, Panjab University, Chandigarh, India. \\ Email: developmentresearch04@gmail.com
}

Received: January 10, 2019 Accepted: February 20, $2019 \quad$ Online Published: March 1, 2019

doi: 10.23918/ijsses.v5i3p263

\begin{abstract}
The in-hand study was undertaken to assess the effectiveness of intervention program on the intelligence quotient, focus factor, decision making ability, creative quotient and academic achievement of students. The longitudinal study was conducted on a sample of 4822 boys and girls aged between 7 and 16 years of age in Chandigarh and Punjab Students of these age groups were the target for the research because this wide range was helpful to analyse the impact of intervention program among respondents of experimental group. In the present research study, socio demographic data sheet, cognitive ability assessment and multiple intelligence scale were used to get the primary quantitative data for further analysis. The procedure involved eleven stages. These stages were followed with the timeline so as to get the reliable findings. The program lasted for around 12 months. During this one year, the respondents in both the groups were assessed 5 times. Academic scores were taken pre and post assessment for analysis. During this time span, a total of $\mathbf{7 2 0}$ customised tasksheets were given to only the respondents belonging to the experimental group while no tasksheet was given to students of the control group. The study found vibrant increase in the cognitive abilities and academic achievement of students.
\end{abstract}

Keywords: Intelligence Quotient, Focus Factor, Decision Making Ability, Creative Quotient, Academic Achievement, Customised Tasksheets

\section{Introduction}

Education and scholastic achievement has a great influence in student's life. The educational system is flourishing at a great pace. However, the methods of education must be improvised from time to time. One such initiative can be the reliable implementation of multiple intelligences in classroom for personalized instruction system based on the cognitive abilities i.e. intelligence quotient, multiple intelligence levels, learning style, dominant thinking pattern, focus factor, decision making ability and creative quotient of students. Educational system should be made learner-centred rather than teacher centred to ensure higher literacy and holistic development of students. In this context, Diseth (2003) examined the intelligence quotient of the boys and girls studying in 11th standard and traced that the intelligence test scores of boys were quite higher than those of girls. Willingham (2004) challenged the statistical base of these results, and criticized the missing loop of a control group in the research study and further mentioned the inappropriately attributing these improvements to multiple intelligence. Teele (2004) conducted a research to study the effectiveness of multiple intelligences approach for students of 5 th grade. Results suggested that when each student's primary intelligence matched with his preferred 
activities, a significant increase in achievement was notified. Nuthana (2007) carried a study on gender differences on academic achievement and found that intelligence quotient was not different among boys and girls. However, gender was witnessed to be the far important variable than intelligence quotient in determining their academic performance. Abdallah (2008) had studied the effectiveness of team teaching based on multiple intelligences. The research findings indicated that a positive relationship existed between teaching based on multiple intelligences and academic achievement among students. Saeidi (2009) conducted research study and found that the objective of lesson plans based on multiple intelligences with specific activities allow the learner to employ their ways of processing and communicating new information, thereby enhancing their academic achievement. Zabelina and Robinson (2010) took up a research study to investigate the relationship between the multiple intelligences and the academic performance achievement levels of school students based on Gardner's multiple intelligence theory. Findings of this study revealed that moderate correlation existed between verbal-linguistic and visual-spatial intelligences and academic performance achievement. Multiple intelligences such as logical-mathematical, visual-spatial, verbal-linguistic, intrapersonal, bodilykinesthetic, interpersonal and naturalistic had a significant positive relationship with academic performance achievement of students. It became clear that multiple intelligences like visual-spatial, verbal-linguistic and interpersonal statistically significant and were able to predict academic performance achievement of students. Dung and Tuan (2011) recorded that learning through a multiple intelligence curriculum, students become aware that they have different strengths and each person has a substantial contribution to make different intellectual functioning. McFarlane (2011) carried a comparative analysis to explore the impact of intelligence on academic achievement of students of secondary stage. The results revealed that intelligence had a significant relationship with academic achievement. Das, Kirby and Jarman (2013) conducted a research work to trace the relationship between multiple intelligences and achievement in chemistry of higher secondary students. It was observed that there was no relation between dimensions of multiple intelligences and achievement in chemistry. In a similar study conducted by Janssen et al. (2014) who studied to investigate the interrelation of multiple intelligences and their correlation to students' academic achievement, found that moderate inter-correlation exists between verbal/linguistic and logical-mathematical intelligences and academic achievement. Acharya, Pal and Sengupta (2015) conducted the study with the purpose to see the relationship between self esteem and academic achievement of secondary school students. The results of the study showed that a positive and significant correlation exists between positive-self males and their academic achievement. Deshmukh (2015) carried a research study to explore high and low self estimation and self concept groups of students with intelligence and academic achievement. Results revealed that high and low self-concept groups intelligence did not differ significantly on academic achievement. In another study conducted by Soares, Lemos, Primi and Almeida (2015), the association between intelligence and academic achievement was established and it was noticed that the IQ scores of students were proportional to their academic scores. The study conducted by Donnelly et al. (2016) has laid down sufficient evidence to imply that there is a positive influence of cognition as well as brain structure and function on academic achievement. Bala, Kaur and Singh (2017) carried a research study and reported that girls think more while taking decisions whereas boys take less time for taking decisions. 


\section{Methodology}

The study was conducted on a sample of 4822 students including boys as well as girls aged between 7 and 16 years of age. Students of these age groups were the target for the research because this wide range was helpful to analyse the impact of intervention program among respondents of experimental group. Respondents were further categorised on the basis of gender and eventually into experimental and control group. In this way the sample was minutely categorised. The experimental group refers to the group under study which receives the intervention during the course of study. The purpose of having the experimental group in the present research study was basically to find out the variation and changes in the dependent variables precisely intelligence quotient, focus factor, decision making ability, creative quotient and academic achievement before, during and after the implementation of intervention program. The control group refers to the group under study which is refrained from the provision of any intervention during the course of study. The purpose of having the control group in the present research study was to compare the variations in the dependent variables of its subjects with that of the changes in the dependent variables of their experimental group counterparts.

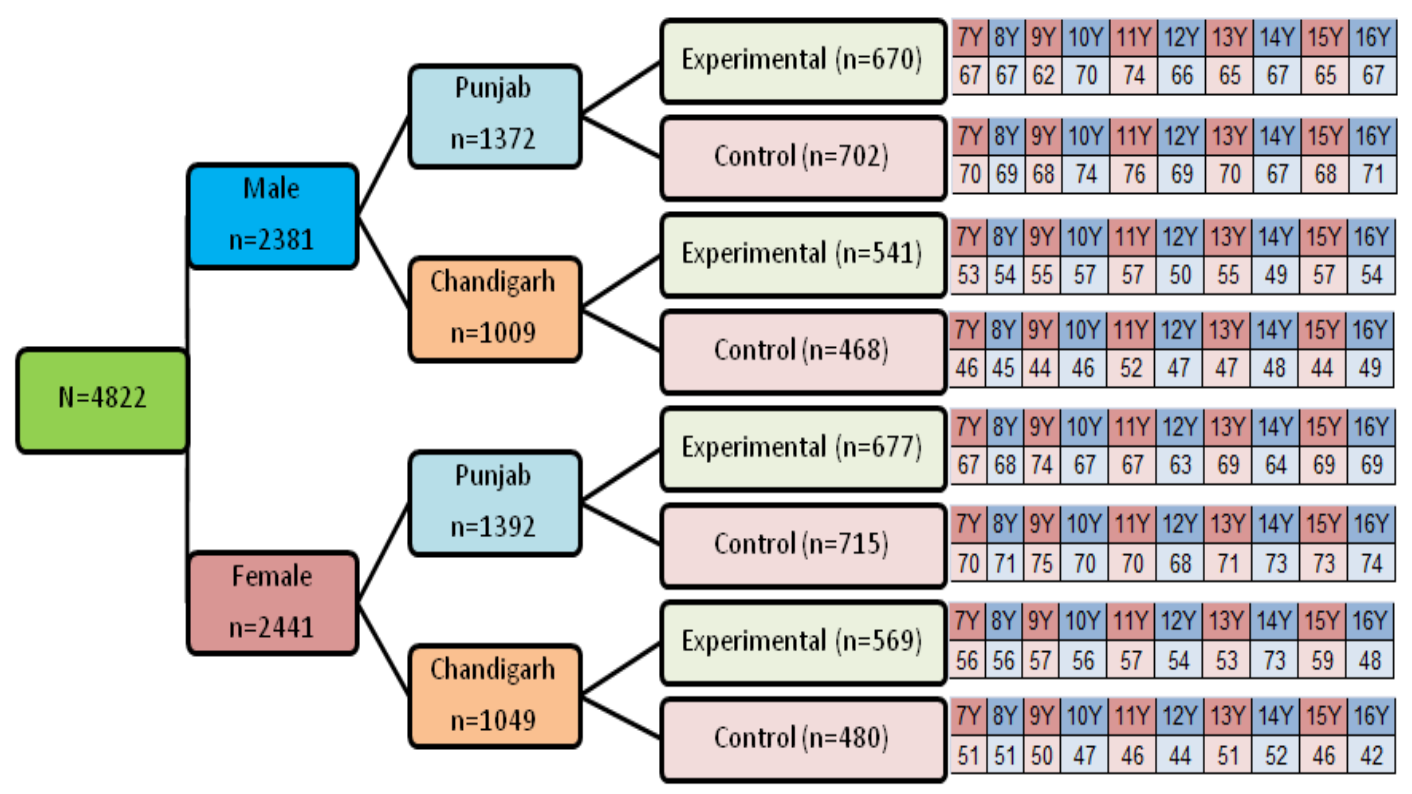

Figure 1: Details of sample 
Table 1: Distribution of sample $(\mathrm{n}=4822)$

\begin{tabular}{|c|c|c|c|c|c|c|c|c|c|c|c|c|}
\hline \multirow{2}{*}{$\begin{array}{c}\text { Age } \\
\text { (years) }\end{array}$} & \multirow[t]{2}{*}{$\mathrm{n}$} & \multirow[t]{2}{*}{$\%$} & \multirow[t]{2}{*}{$\mathrm{M} / \mathrm{F}$} & \multirow[t]{2}{*}{$\mathrm{N}$} & \multirow[t]{2}{*}{$\%$} & \multirow[t]{2}{*}{ Place } & \multirow[t]{2}{*}{$\mathrm{n}$} & \multirow[t]{2}{*}{$\%$} & \multicolumn{2}{|c|}{$\begin{array}{l}\text { Experimental } \\
\text { Group }\end{array}$} & \multicolumn{2}{|c|}{$\begin{array}{l}\text { Control } \\
\text { Group }\end{array}$} \\
\hline & & & & & & & & & $\mathrm{N}$ & $\%$ & $\mathrm{~N}$ & $\%$ \\
\hline \multirow{4}{*}{7} & \multirow{4}{*}{480} & \multirow{4}{*}{9.95} & \multirow{2}{*}{$\mathrm{M}$} & \multirow{2}{*}{236} & \multirow{2}{*}{4.89} & $\mathrm{~Pb}$ & 137 & 2.84 & 67 & 1.39 & 70 & 1.45 \\
\hline & & & & & & Chd & 99 & 2.05 & 53 & 1.1 & 46 & 0.95 \\
\hline & & & \multirow{2}{*}{$\mathrm{F}$} & \multirow{2}{*}{244} & \multirow{2}{*}{5.06} & $\mathrm{~Pb}$ & 137 & 2.84 & 67 & 1.39 & 70 & 1.45 \\
\hline & & & & & & Chd & 107 & 2.22 & 56 & 1.16 & 51 & 1.06 \\
\hline \multirow{4}{*}{8} & \multirow{4}{*}{481} & \multirow{4}{*}{9.98} & \multirow{2}{*}{ M } & 235 & 487 & $\mathrm{~Pb}$ & 136 & 2.82 & 67 & 1.39 & 69 & 1.43 \\
\hline & & & & 255 & 4.81 & Chd & 99 & 2.05 & 54 & 1.12 & 45 & 0.93 \\
\hline & & & F & 246 & 51 & $\mathrm{~Pb}$ & 139 & 2.88 & 68 & 1.41 & 71 & 1.47 \\
\hline & & & $\Gamma$ & 240 & 3.1 & Chd & 107 & 2.22 & 56 & 1.16 & 51 & 1.06 \\
\hline & & & & & 475 & $\mathrm{~Pb}$ & 130 & 2.7 & 62 & 1.29 & 68 & 1.41 \\
\hline 0 & 185 & 1006 & $\mathrm{M}$ & $\angle 29$ & 4.15 & Chd & 99 & 2.05 & 55 & 1.14 & 44 & 0.91 \\
\hline 9 & $40 J$ & 10.00 & $F$ & 256 & 531 & $\mathrm{~Pb}$ & 149 & 3.09 & 74 & 1.53 & 75 & 1.56 \\
\hline & & & 1 & $2 J 0$ & 3.01 & Chd & 107 & 2.22 & 57 & 1.18 & 50 & 1.04 \\
\hline & & & $M$ & 247 & 512 & $\mathrm{~Pb}$ & 144 & 2.99 & 70 & 1.45 & 74 & 1.53 \\
\hline 10 & 487 & 101 & 101 & 241 & 3.12 & Chd & 103 & 2.14 & 57 & 1.18 & 46 & 0.95 \\
\hline 10 & 401 & 10.1 & $\mathrm{~F}$ & 240 & 408 & $\mathrm{~Pb}$ & 137 & 2.84 & 67 & 1.39 & 70 & 1.45 \\
\hline & & & $\Gamma$ & 240 & 4.90 & Chd & 103 & 2.14 & 56 & 1.16 & 47 & 0.97 \\
\hline & & & $M$ & 250 & 527 & $\mathrm{~Pb}$ & 150 & 3.11 & 74 & 1.53 & 76 & 1.58 \\
\hline 11 & 190 & 1035 & IVI & 259 & 5.51 & Chd & 109 & 2.26 & 57 & 1.18 & 52 & 1.08 \\
\hline 11 & 499 & 10.53 & $F$ & 240 & 408 & $\mathrm{~Pb}$ & 137 & 2.84 & 67 & 1.39 & 70 & 1.45 \\
\hline & & & $\Gamma$ & 240 & 4.90 & Chd & 103 & 2.14 & 57 & 1.18 & 46 & 0.95 \\
\hline & & & $M$ & 232 & 481 & $\mathrm{~Pb}$ & 135 & 2.8 & 66 & 1.37 & 69 & 1.43 \\
\hline 12 & 461 & 956 & $1 \mathrm{VI}$ & $2 J 2$ & 4.01 & Chd & 97 & 2.01 & 50 & 1.04 & 47 & 0.97 \\
\hline 12 & 401 & 9.50 & E & 220 & 475 & $\mathrm{~Pb}$ & 131 & 2.72 & 63 & 1.31 & 68 & 1.41 \\
\hline & & & $\Gamma$ & 229 & $4.1 J$ & Chd & 98 & 2.03 & 54 & 1.12 & 44 & 0.91 \\
\hline & & & $M$ & 237 & 401 & $\mathrm{~Pb}$ & 135 & 2.8 & 65 & 1.35 & 70 & 1.45 \\
\hline 13 & 181 & 008 & NI & 251 & 4.91 & Chd & 102 & 2.12 & 55 & 1.14 & 47 & 0.97 \\
\hline 15 & 401 & 9.90 & $F$ & 244 & 506 & $\mathrm{~Pb}$ & 140 & 2.9 & 69 & 1.43 & 71 & 1.47 \\
\hline & & & $\Gamma$ & 244 & 0.00 & Chd & 104 & 2.16 & 53 & 1.1 & 51 & 1.06 \\
\hline & & & M & 231 & 479 & $\mathrm{~Pb}$ & 134 & 2.78 & 67 & 1.39 & 67 & 1.39 \\
\hline 14 & 493 & 1027 & & & & Chd & 97 & 2.01 & 49 & 1.02 & 48 & 1 \\
\hline & & 10.22 & $F$ & 262 & 5,43 & $\mathrm{~Pb}$ & 137 & 2.84 & 64 & 1.33 & 73 & 1.51 \\
\hline & & & $\mathrm{F}$ & 202 & 5.43 & Chd & 125 & 2.59 & 73 & 1.51 & 52 & 1.08 \\
\hline & & & M & 234 & 485 & $\mathrm{~Pb}$ & 133 & 2.76 & 65 & 1.35 & 68 & 1.41 \\
\hline 15 & 481 & 098 & IVI & 234 & $4.0 \mathrm{~J}$ & Chd & 101 & 2.09 & 57 & 1.18 & 44 & 0.91 \\
\hline $1 \mathrm{~J}$ & 401 & 3.90 & $\mathrm{~F}$ & 247 & 512 & $\mathrm{~Pb}$ & 142 & 2.94 & 69 & 1.43 & 73 & 1.51 \\
\hline & & & F & 241 & 5.12 & Chd & 105 & 2.18 & 59 & 1.22 & 46 & 0.95 \\
\hline
\end{tabular}




\begin{tabular}{|c|c|c|c|c|c|c|c|c|c|c|c|c|}
\hline \multirow{4}{*}{16} & \multirow{4}{*}{474} & \multirow{3}{*}{9.83} & \multirow{2}{*}{$\mathrm{M}$} & \multirow{2}{*}{241} & \multirow{2}{*}{5} & $\mathrm{~Pb}$ & 138 & 2.86 & 67 & 1.39 & 71 & 1.47 \\
\hline & & & & & & Chd & 103 & 2.14 & 54 & 1.12 & 49 & 1.02 \\
\hline & & & \multirow{2}{*}{$\mathrm{F}$} & \multirow{2}{*}{233} & \multirow{2}{*}{4.83} & $\mathrm{~Pb}$ & 143 & 2.97 & 69 & 1.43 & 74 & 1.53 \\
\hline & & & & & & Chd & 90 & 1.87 & 48 & 1 & 42 & 0.87 \\
\hline
\end{tabular}

In the present research study, socio demographic data sheet, cognitive ability assessment and multiple intelligence scale were used to get the primary quantitative data for further analysis. The socio demographic data included the brief description of the respondents including their name, age, grade, place of residence, family type, family size, parental education and occupation to gain the maximum possible information about the respondents. Cognitive ability assessment is a standardized assessment. It is a valid and reliable tool to assess intelligence quotient, focus factor i.e. focused attention, decision making ability and creative quotient of students. The assessment caters to the students from 7 to 16 years of age and gives the quantitative analysis of intelligence quotient; focus factor i.e. focused attention, decision making ability and creative quotient. Students were given instructions before starting the assessment. The assessment has been divided into two sections- part A and part B. Part A contained 70 multiple choice questions. Each question carried four options. Only one of these options made the meaningful answer. Students were instructed to write the starting time as well as completion time for both the parts of the assessment. The students were told the standard time for taking the assessment which was 40 minutes for children from 7 to 11 years of age while for those aging 12 to 16, the standard recommended time was 30 minutes. However, the students were allowed to complete the assessment but they were instructed to write the completion time. Part B contained 10 multiple choice questions. Each question carried four options. All the options carried a different weightage as answer. The assessment booklets were collected and evaluated as per the atomized scoring key based on microsoft excel worksheet. The raw scores were thereafter converted into the values of the said parameters based on the set standards. Multiple intelligence scale developed and standardized by the investigator was used to assess the multiple intelligence levels, primary dominant intelligence, dominant thinking pattern and self estimation level of the respondents. Academic achievement was considered as per the scores obtained by the respondents in school examinations before and after the intervention program. The tasksheets were customized according to the dominant intelligence and cognitive profile of each respondent in the experimental group.

\section{Procedure and Intervention Program}

The procedure involved eleven stages. These stages were followed with the timeline so as to get the reliable findings. 
Table 2: Procedure followed in experimental and control group

\begin{tabular}{|l|c|c|}
\hline & Experimental Group & Control Group \\
\hline Stage 1 & \multicolumn{2}{|c|}{ Rapport Building } \\
\hline Stage 2 & Consent of respondents and socio-demographic data collection \\
\hline Stage 3 & Administration of pre intervention test and assessment (TA-1) \\
\hline Stage 4 & Intervention Quarter-1 & No Intervention \\
\hline Stage 5 & \multicolumn{2}{|c|}{ Administration of first tracker test (TA-2) } \\
\hline Stage 6 & Intervention Quarter-2 & No Intervention \\
\hline Stage 7 & \multicolumn{2}{|c|}{ Administration of first tracker test (TA-3) } \\
\hline Stage 8 & Intervention Quarter-3 Intervention \\
\hline Stage 9 & \multicolumn{2}{|c|}{ Administration of first tracker test (TA-4) } \\
\hline Stage 10 & Intervention Quarter-4 & No Intervention \\
\hline Stage 11 & Administration of post intervention test and assessment (TA-5) \\
\hline
\end{tabular}

Stage 1: Rapport Building

Group: Experimental and Control

At the initial stage, rapport was built with respondents. During the rapport building process, researcher had taken up 30-45 minutes session for each group consisting of 30-40 students. At this time, the researcher introduced herself and encouraged the students to introduce themselves. Later, informal discussion was initiated concerning student life. General discussion and exchange of ideas in a healthy manner motivated the students to feel comfortable and interested in the program.

Stage 2: Consent of respondents and socio-demographic data collection

Group: Experimental and Control

The respondents were briefly told about the entire program. They were informed about the purpose and implications of the entire program. The significance of their participation was shared with them. Although the written consent had been received through parents with their signatures through a circular, still it was important to take the consent and willingness of respondents. Thus the formal consent of students was also taken. They were also informed that they can choose whether to participate in the study or not and that they were not bound as such and can opt out of the program as and when they wish. However they were encouraged to participate in the complete program. They were ensured that the data shall be kept confidential and would only be used for the research purposes. Later, their sociodemographic data was collected.

Stage 3: Administration of pre intervention test and assessment (TA-1)

Group: Experimental and Control 
The respondents were given instructions in a simple manner using English, Hindi and Punjabi languages. Their doubts were cleared as per the queries. Start time of the test was recorded. The test and assessment was conducted. The researcher supervised the students while taking the test. As and when any student raised a query, it was handled as per the standard. They were helped to understand the question whenever any respondent needed this help. However, no hint or answer was shared with any respondent. They were allowed to complete the test and assessment. They were informed to write the stop time after completing the test. The academic scores of all respondents were also collected for research purpose.

Stage 4: Intervention Quarter-1

Group: Experimental

(No intervention in control group)

In the first quarter after the first test and assessment TA-1, the results of the pre test were analysed along with the academic scores of the students. One hundred and eighty task sheets were given to the respondents in experimental group for three months. Customized task sheets pertaining to the dominant intelligence of each student were given. Proper instructions were given about attempting the task sheets. They were required to attempt 2 task sheets daily. They had to attempt the task sheets in school under the supervision of their teacher. Although there was no time limit but the average time required for completing each task sheet was 5-10 minutes. They had to write the start time and stop time at the bottom of each task sheet. Tasksheets were customised according to each student's cognitive abilities and primary intelligence of the student as assessed through the cognitive ability assessment. The program coordinator from school had to make sure that the task sheets are done regularly under the supervision of their teachers. The students were given proper instructions regarding the program. The research scholar was kept herself in contact with the program coordinator on weekly basis to take feedback and resolve issues, if any. While communication regarding the task sheets, the unique code given on top right corner of the tasksheet was to be shared.

Stage 5: Administration of first tracker test (TA-2)

Group: Experimental and Control

After three months, the first tracker test was conducted. The tracker test was administered on the experimental as well as control group. The purpose of the tracker test was to monitor the progress of the experimental as well as control group in terms of intelligence quotient, focus factor, decision making ability and creative quotient. The respondents were given instructions in a simple manner in English, Hindi and Punjabi medium. Their doubts were cleared prior to the tracker test. Start time of the test was recorded. The test was conducted. The researcher supervised the students during the test. If any student raised query, it was taken care of as per the set standards. They were assisted to understand the question if required but, no hint or answer was shared with any respondent. They were allowed to complete the test and assessment. They were well informed to mention the stop time of the test.

Stage 6: Intervention Quarter-2

Group: Experimental 
(No intervention in control group)

After the first tracker test and assessment TA-2, the reports and findings of the first tracker test and assessment were analyzed to assign the taksheets for the second quarter that were assigned keeping individual progress in mind. Another set of customized one hundred and eighty task sheets were given to the respondents in experimental group for next three months. The proper implementation of the program was checked from time to time by visiting the school and keeping in contact with the coordinator and teachers through telephonic conversation.

Stage 7: Administration of second tracker test (TA-3)

Group: Experimental and Control

After six months of the completion of the program. the second tracker test was conducted. The tracker test was administered on the experimental as well as control group. The purpose of the tracker test was to monitor the progress of the experimental as well as control group in terms of intelligence quotient, focus factor, decision making ability and creative quotient. Instructions were shared and the doubts were cleared. The test was conducted. The researcher supervised the students during the test. They were requested to mention the stop time of the test.

Stage 8: Intervention Quarter-3

Group: Experimental

(No intervention in control group)

In the third quarter after the first test and assessment TA-2, a new set of customized one hundred and eighty task sheets were again given to the respondents in experimental group for next three months. The respondents had to complete two sheets daily along with their regular work done at class and home.

Stage 9: Administration of third tracker test (TA-4)

Group: Experimental and Control

After nine months of the completion of the program, to monitor and track their progress, third tracker test was administered on the respondents of experimental as well as control group. The tracker test was conducted on the experimental as well as control group. Start and stop time was recorded for the test.

Stage 10: Intervention Quarter-4

Group: Experimental

(No intervention in control group)

In the fourth quarter after the fourth test and assessment TA-4, further, a set of customized one hundred and eighty task sheets were given to the respondents in experimental group for next three months before conducting the post intervention test and assessment.

Stage 11: Administration of post intervention test and assessment (TA-5)

Group: Experimental and Control 
After twelve months of the completion of the program, the fifth and the final post tracker test and assessment was conducted. The tracker test was administered on the experimental as well as control group. The purpose of the tracker test was to track the progress of the respondents in the experimental as well as control group in terms of intelligence quotient, focus factor, decision making ability and creative quotient. They were well informed to mention the stop time of the test. Along with the results of the test and assessment, the academic scores of the student were again taken for analysis for the research purpose.

Therefore, the program lasted for around 12 months. During this one year, the respondents in both the groups were assessed 5 times. Academic scores were taken pre and post assessment for analysis. During this time span, a total of 720 customised tasksheets were given to only the respondents belonging to the experimental group while no tasksheet was given to students of the control group.

\section{Results}

It is very important to analyse the data and derive the results. In the present study, the sociodemographic data was obtained. The data analysis included cross sectional as well as longitudinal approach. Cross sectional study was done to compare different groups while longitudinal study comprised of comparing changes in the variables under study within the same groups to find out the impact of intervention program. The SPSS software was used to analyse the data obtained from the respondents. The descriptive statistics and the inferential statistics were calculated. Descriptive statistics included mean, and standard deviation. Inferential statistics included the unpaired two tailed ttest for the cross sectional analysis. In this context, different groups were compared for the same variables at different stages of the research study. For this purpose, the respondents were compared in terms of their IQ, FF, DMA, CQ and marks at all the sages. The former four parameters were measured five times during the study while the marks were compared twice. Respondents based on group (experimental and control group), gender (males and females) and place (Chandigarh and Punjab). Further, the longitudinal analysis was also done. The respondents were compared to assess the impact of intervention program on cognitive abilities and academic achievement of respondents in experimental and control groups at five different stages of the intervention program. In this case, two tailed paired ttest was applied to the data obtained from the respondents. The level of significance of the difference in the mean values of the groups was evaluated and thus the inferences were drawn after the data analysis. It is evident that the primary natural intelligence of $13.45 \%$ respondents was noticed to be musical, while $12.62 \%$ of them possessed kinesthetic as compared to $13.58 \%$ who were having intrapersonal intelligence. $13.31 \%$ had high interpersonal intelligence whereas $5.14 \%$ were linguistic in nature. Logical intelligence was possessed by $11.61 \%$ respondents. 
Table 3: Personal and socio demographic profile

\begin{tabular}{|c|c|c|c|}
\hline \multicolumn{2}{|l|}{ Parameters } & \multirow{2}{*}{$\begin{array}{l}n \\
649\end{array}$} & \multirow{2}{*}{$\begin{array}{l}\% \\
13.46\end{array}$} \\
\hline \multirow[t]{9}{*}{ Primary natural Intelligence } & Musical & & \\
\hline & Kinesthetic & 609 & 12.63 \\
\hline & Intrapersonal & 655 & 13.58 \\
\hline & Interpersonal & 642 & 13.31 \\
\hline & Linguistic & 248 & 5.14 \\
\hline & Logical & 560 & 11.61 \\
\hline & Spatial & 367 & 7.61 \\
\hline & Cosmic & 395 & 8.19 \\
\hline & Naturalist & 697 & 14.45 \\
\hline \multicolumn{2}{|l|}{ Total } & 4822 & 100.00 \\
\hline \multirow[t]{3}{*}{ Dominant Thinking Pattern } & Creative & 3736 & 77.48 \\
\hline & Logical & 1073 & 22.25 \\
\hline & Balanced & 13 & 0.27 \\
\hline \multicolumn{2}{|l|}{ Total } & 4822 & 100.00 \\
\hline \multirow[t]{6}{*}{ Estimation Level } & Highly Overestimated & 2 & 0.04 \\
\hline & Overestimated & 163 & 3.38 \\
\hline & Slightly Overestimated & 806 & 16.72 \\
\hline & Perfect Estimation & 3390 & 70.30 \\
\hline & Underestimated & 360 & 7.47 \\
\hline & Highly Underestimated & 101 & 2.09 \\
\hline \multicolumn{2}{|l|}{ Total } & 4822 & 100.00 \\
\hline \multirow[t]{2}{*}{ Family Type } & Joint & 2023 & 41.95 \\
\hline & Nuclear & 2799 & 58.05 \\
\hline \multicolumn{2}{|l|}{ Total } & 4822 & 100.00 \\
\hline \multirow[t]{4}{*}{ Family Size } & Small (Up to 3members) & 158 & 3.28 \\
\hline & Medium (4-6 members) & 3545 & 73.52 \\
\hline & Medium Large (7-10 members) & 1119 & 23.21 \\
\hline & Large (More than 10 members) & 0 & 0.00 \\
\hline \multicolumn{2}{|l|}{ Total } & 4822 & 100.00 \\
\hline
\end{tabular}




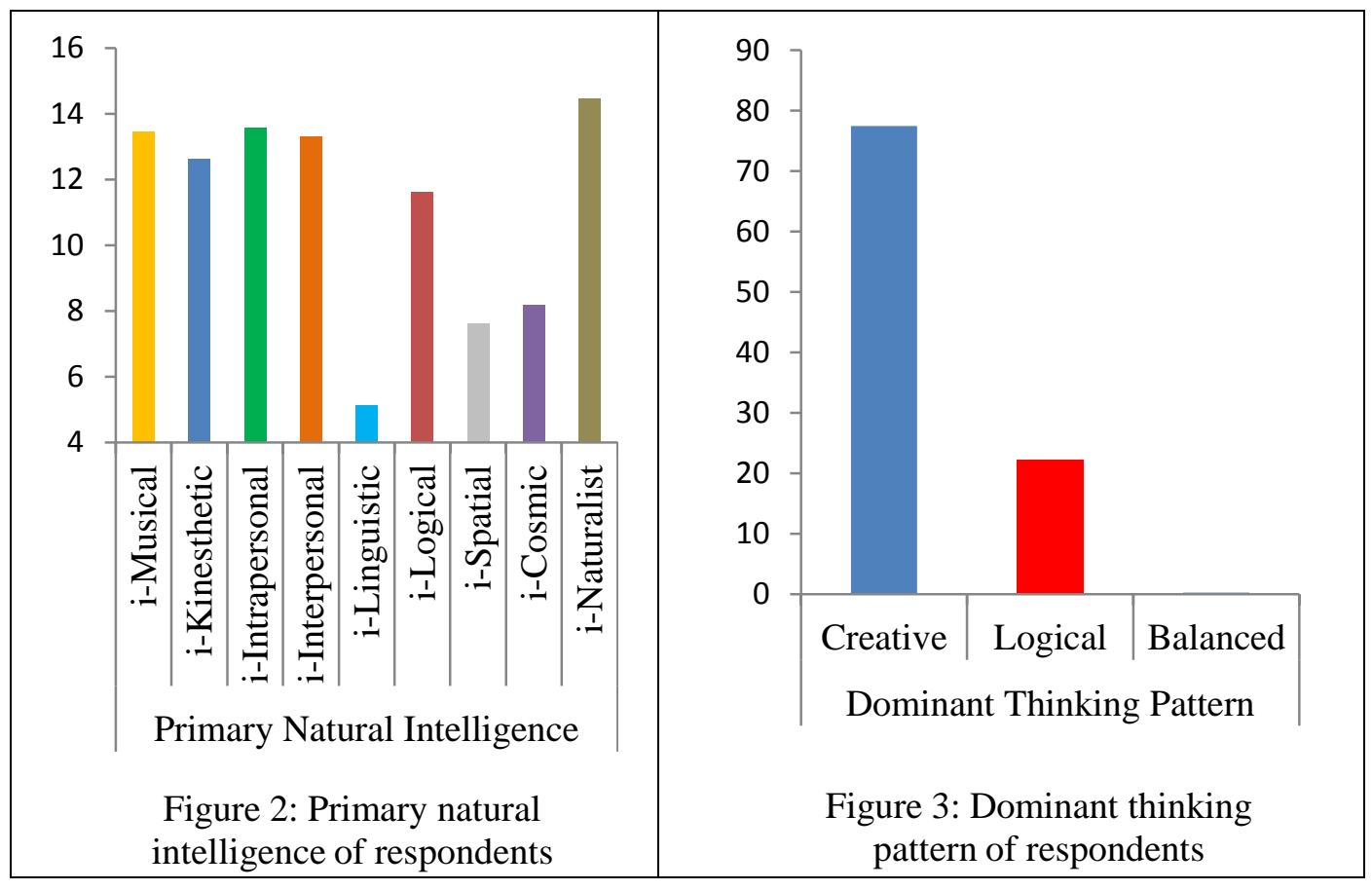

It was seen that $7.61 \%$ preferred to learn by spatial methods. However, cosmic intelligence was high among $8.19 \%$ respondents as compared to $14.45 \%$ who were highly naturalist. $77.47 \%$ respondents had creative bent of mind as compared to $22.25 \%$ of them who had logical dominant thinking pattern. There were $0.26 \%$ respondents who had a balance in logical and creative thinking style. $0.04 \%$ respondents highly overestimated themselves, while there were $3.38 \%$ who overestimated themselves and further $16.71 \%$ of them who slightly overestimated themselves. In terms of estimation level, figure 4 shows that $70.30 \%$ of the respondents had the perfect estimation of themselves. There were $7.46 \%$ who underestimated themselves in contrast to $2.09 \%$ who highly underestimated themselves. $41.95 \%$ respondents belonged to joint family whereas rest of them belonged to nuclear family. $3.27 \%$ respondents reside in small families whereas $73.51 \%$ of them belonged to medium families. 


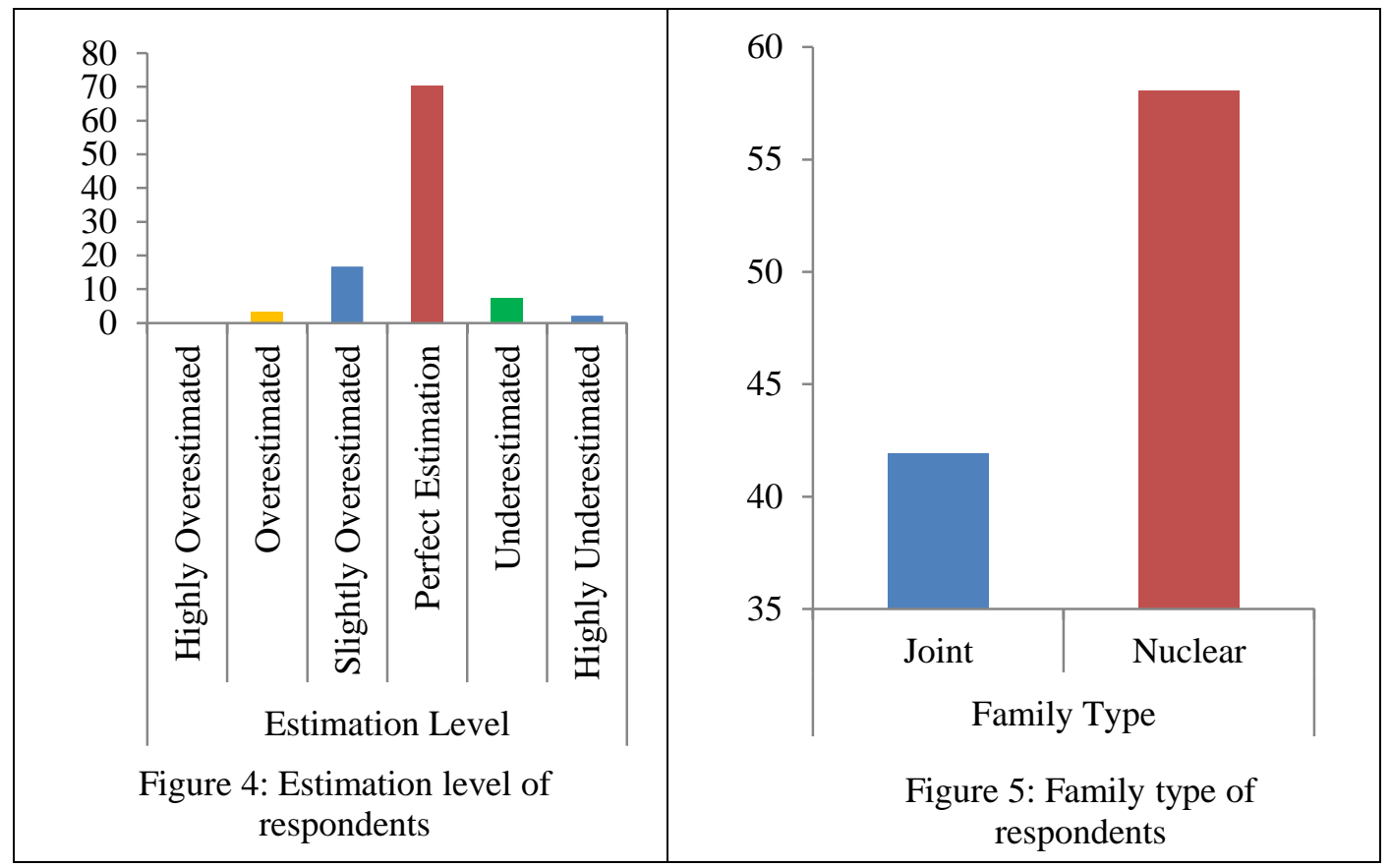

Table 4: Parental education and occupation status

\begin{tabular}{|c|c|c|c|c|c|}
\hline \multirow[t]{15}{*}{ Parental Education Status } & & \multicolumn{2}{|c|}{ Mother } & \multicolumn{2}{|c|}{ Father } \\
\hline & & $\mathrm{n}$ & $\%$ & $\mathrm{~N}$ & $\%$ \\
\hline & $10^{\text {th }}$ & 809 & 16.77 & 752 & 15.60 \\
\hline & $11^{\text {th }}$ & 3 & 0.06 & 2 & 0.04 \\
\hline & $12^{\text {th }}$ & 1392 & 28.86 & 1316 & 27.29 \\
\hline & B Ed & 30 & 0.62 & 115 & 2.38 \\
\hline & BA & 2095 & 43.44 & 1837 & 38.10 \\
\hline & BDS & 1 & 0.02 & 14 & 0.29 \\
\hline & $\mathrm{M} \mathrm{Sc}$ & 56 & 1.16 & 142 & 2.94 \\
\hline & MBBS & 1 & 0.02 & 2 & 0.04 \\
\hline & MA & 435 & 9.02 & 467 & 9.68 \\
\hline & $\mathrm{BE}$ & 0 & 0 & 102 & 2.12 \\
\hline & M Com & 0 & 0 & 65 & 1.35 \\
\hline & M Ed & 0 & 0 & 7 & 0.15 \\
\hline & MD & 0 & 0 & 1 & 0.02 \\
\hline \multicolumn{2}{|l|}{ Total } & 4822 & 100 & 4822 & 100.00 \\
\hline \multirow[t]{3}{*}{ Parental Occupation } & Private & 234 & 4.85 & 3082 & 63.92 \\
\hline & Govt & 99 & 2.05 & 1695 & 35.15 \\
\hline & Not Working & 4489 & 93.09 & 45 & 0.93 \\
\hline \multicolumn{2}{|l|}{ Total } & 4822 & 100 & 4822 & 100.00 \\
\hline
\end{tabular}

Moreover, $23.20 \%$ of them belonged to medium large families. When the educational status of their mothers was analysed, it was seen that the highest proportion has completed graduation in arts. Besides, 
the majority of fathers too possessed the same degree. In terms of their occupation, most of mothers were not working whereas in case of fathers, a larger proportion was working in private sectors.

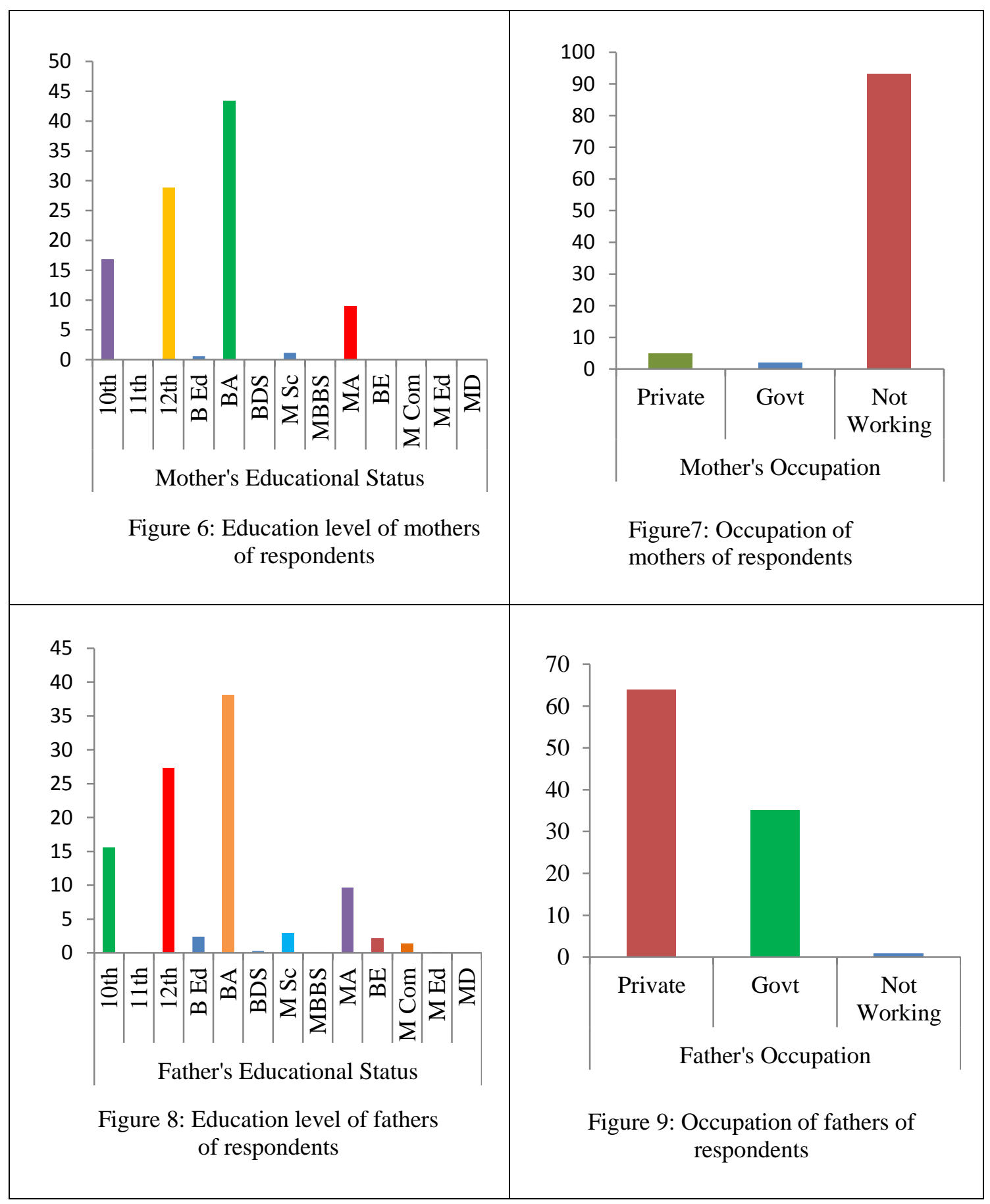


Table 5: Increase in mean value of IQ of respondents in experiment group

\begin{tabular}{|c|c|c|c|c|c|c|c|c|c|c|c|c|}
\hline Age & Group & & IQ1 & IQ2 & IQ3 & IQ4 & IQ5 & $\begin{array}{l}\text { IQ2- } \\
\text { IQ1 }\end{array}$ & $\begin{array}{l}\text { IQ3- } \\
\text { IQ2 }\end{array}$ & $\begin{array}{l}\text { IQ4- } \\
\text { IQ3 }\end{array}$ & $\begin{array}{l}\text { IQ5- } \\
\text { IQ4 }\end{array}$ & $\begin{array}{l}\text { IQ5- } \\
\text { IQ1 }\end{array}$ \\
\hline \multirow[t]{4}{*}{7} & \multirow[t]{2}{*}{ Male } & Chd & 105.17 & 109.43 & 113.69 & 123.55 & 129.75 & 4.26 & 4.26 & 9.87 & 6.20 & 24.59 \\
\hline & & $\mathrm{Pb}$ & 93.74 & 98.13 & 102.52 & 112.37 & 118.24 & 4.39 & 4.39 & 9.85 & 5.86 & 24.50 \\
\hline & \multirow[t]{2}{*}{ Female } & Chd & 113.20 & 118.70 & 124.20 & 135.19 & 143.17 & 5.50 & 5.50 & 10.99 & 7.98 & 29.97 \\
\hline & & $\mathrm{Pb}$ & 78.00 & 93.39 & 122.27 & 133.79 & 142.07 & 15.39 & 28.87 & 11.52 & 8.28 & 64.07 \\
\hline \multirow[t]{4}{*}{8} & \multirow[t]{2}{*}{ Male } & Chd & 107.25 & 114.53 & 121.81 & 133.35 & 140.11 & 7.28 & 7.28 & 11.54 & 6.76 & 32.87 \\
\hline & & $\mathrm{Pb}$ & 103.55 & 111.07 & 118.60 & 130.10 & 136.87 & 7.52 & 7.52 & 11.50 & 6.77 & 33.32 \\
\hline & \multirow[t]{2}{*}{ Female } & Chd & 105.93 & 106.73 & 120.43 & 129.34 & 135.47 & 0.80 & 13.70 & 8.91 & 6.13 & 29.55 \\
\hline & & $\mathrm{Pb}$ & 100.29 & 105.08 & 114.87 & 124.14 & 130.27 & 4.79 & 9.79 & 9.27 & 6.13 & 29.98 \\
\hline \multirow[t]{4}{*}{9} & \multirow[t]{2}{*}{ Male } & Chd & 102.37 & 109.95 & 117.54 & 126.59 & 132.49 & 7.58 & 7.58 & 9.06 & 5.89 & 30.12 \\
\hline & & $\mathrm{Pb}$ & 105.73 & 113.27 & 120.81 & 131.34 & 137.42 & 7.54 & 7.54 & 10.53 & 6.08 & 31.69 \\
\hline & \multirow[t]{2}{*}{ Female } & Chd & 105.95 & 106.84 & 121.87 & 131.11 & 137.04 & 0.89 & 15.03 & 9.24 & 5.93 & 31.09 \\
\hline & & $\mathrm{Pb}$ & 106.27 & 111.78 & 121.58 & 130.92 & 136.92 & 5.51 & 9.81 & 9.34 & 6.00 & 30.65 \\
\hline \multirow[t]{4}{*}{10} & Male & Chd & 104.42 & 109.93 & 115.70 & 123.24 & 128.70 & 5.52 & 5.76 & 7.54 & 5.46 & 24.29 \\
\hline & & $\mathrm{Pb}$ & 103.05 & 108.65 & 114.54 & 122.77 & 128.31 & 5.60 & 5.89 & 8.23 & 5.54 & 25.27 \\
\hline & \multirow[t]{2}{*}{ Female } & Chd & 104.04 & 112.00 & 115.45 & 123.84 & 129.41 & 7.95 & 3.46 & 8.38 & 5.58 & 25.37 \\
\hline & & $\mathrm{Pb}$ & 100.74 & 102.54 & 111.94 & 120.26 & 125.73 & 1.80 & 9.40 & 8.32 & 5.46 & 24.99 \\
\hline \multirow[t]{4}{*}{11} & \multirow[t]{2}{*}{ Male } & Chd & 103.15 & 107.04 & 111.16 & 119.58 & 125.03 & 3.88 & 4.13 & 8.42 & 5.45 & 21.88 \\
\hline & & $\mathrm{Pb}$ & 99.26 & 102.18 & 105.29 & 113.75 & 119.01 & 2.91 & 3.12 & 8.46 & 5.26 & 19.75 \\
\hline & \multirow[t]{2}{*}{ Female } & Chd & 96.09 & 100.81 & 103.89 & 110.62 & 115.59 & 4.73 & 3.08 & 6.73 & 4.97 & 19.50 \\
\hline & & $\mathrm{Pb}$ & 99.48 & 100.28 & 107.03 & 114.44 & 119.62 & 0.80 & 6.75 & 7.41 & 5.18 & 20.14 \\
\hline \multirow[t]{4}{*}{12} & \multirow[t]{2}{*}{ Male } & Chd & 98.25 & 99.04 & 100.00 & 101.65 & 107.45 & 0.79 & 0.96 & 1.65 & 5.80 & 9.20 \\
\hline & & $\mathrm{Pb}$ & 96.01 & 96.91 & 96.93 & 99.71 & 105.46 & 0.90 & 0.02 & 2.78 & 5.75 & 9.45 \\
\hline & \multirow[t]{2}{*}{ Female } & Chd & 83.79 & 84.22 & 86.00 & 87.49 & 92.54 & 0.43 & 1.78 & 1.49 & 5.05 & 8.75 \\
\hline & & $\mathrm{Pb}$ & 83.68 & 85.00 & 87.00 & 88.02 & 93.44 & 1.32 & 1.99 & 1.03 & 5.42 & 9.76 \\
\hline \multirow[t]{4}{*}{13} & \multirow[t]{2}{*}{ Male } & Chd & 94.33 & 103.17 & 114.11 & 118.61 & 123.79 & 8.83 & 10.94 & 4.50 & 5.18 & 29.46 \\
\hline & & $\mathrm{Pb}$ & 93.10 & 102.14 & 113.28 & 117.90 & 123.06 & 9.05 & 11.14 & 4.62 & 5.16 & 29.96 \\
\hline & \multirow[t]{2}{*}{ Female } & Chd & 95.00 & 101.00 & 116.26 & 122.13 & 127.50 & 6.00 & 15.26 & 5.86 & 5.38 & 32.50 \\
\hline & & $\mathrm{Pb}$ & 92.92 & 97.84 & 113.25 & 119.28 & 124.53 & 4.92 & 15.41 & 6.03 & 5.25 & 31.62 \\
\hline \multirow[t]{4}{*}{14} & \multirow[t]{2}{*}{ Male } & Chd & 96.19 & 104.96 & 114.54 & 120.44 & 125.75 & 8.77 & 9.57 & 5.90 & 5.31 & 29.56 \\
\hline & & $\mathrm{Pb}$ & 97.67 & 106.58 & 116.30 & 122.28 & 127.67 & 8.91 & 9.72 & 5.98 & 5.39 & 30.00 \\
\hline & \multirow[t]{2}{*}{ Female } & Chd & 89.54 & 103.50 & 106.62 & 111.31 & 116.16 & 13.97 & 3.11 & 4.69 & 4.85 & 26.62 \\
\hline & & $\mathrm{Pb}$ & 91.29 & 93.30 & 108.70 & 114.19 & 119.20 & 2.01 & 15.41 & 5.48 & 5.02 & 27.91 \\
\hline \multirow[t]{4}{*}{15} & Male & Chd & 91.48 & 98.88 & 106.89 & 113.13 & 118.17 & 7.41 & 8.01 & 6.23 & 5.05 & 26.70 \\
\hline & & $\mathrm{Pb}$ & 94.47 & 102.10 & 110.34 & 117.68 & 122.95 & 7.63 & 8.24 & 7.34 & 5.27 & 28.48 \\
\hline & Female & Chd & 91.44 & 91.86 & 103.85 & 112.66 & 118.46 & 0.42 & 11.99 & 8.81 & 5.80 & 27.02 \\
\hline & & $\mathrm{Pb}$ & 91.36 & 95.18 & 103.42 & 112.85 & 118.78 & 3.83 & 8.23 & 9.43 & 5.93 & 27.42 \\
\hline
\end{tabular}




\begin{tabular}{|l|l|l|l|l|l|l|l|l|l|l|l|l|}
\hline 16 & Male & Chd & 95.49 & 100.36 & 105.48 & 114.02 & 119.80 & 4.87 & 5.12 & 8.55 & 5.77 & 24.31 \\
\cline { 3 - 12 } & & $\mathrm{Pb}$ & 94.01 & 98.80 & 103.84 & 112.55 & 118.27 & 4.80 & 5.04 & 8.71 & 5.72 & 24.27 \\
\cline { 2 - 13 } & \multirow{2}{*}{ Female } & Chd & 93.84 & 98.63 & 103.66 & 110.60 & 115.84 & 4.79 & 5.03 & 6.93 & 5.24 & 22.00 \\
\cline { 3 - 12 } & & $\mathrm{Pb}$ & 95.65 & 100.53 & 105.66 & 112.75 & 118.00 & 4.88 & 5.13 & 7.09 & 5.25 & 22.35 \\
\hline
\end{tabular}

When the difference in subsequent IQ was reported, it was notified that there was maximum increase of 15.39 from IQ 1 to IQ 2 among 7 years old females from Punjab while the lowest surge was witnessed among 15 years old females from Chandigarh. The IQ rose by 28.87 points from second to third test among 7 years old females from Punjab while the least change was an increase by 0.02 points in case of 12 years old males from Punjab. The IQ 4 was found to be 11.54 points higher than the previous among 8 years old males from Chandigarh while the least change was an increase by 1.03 points in case of 12 years old females from Punjab. There was maximum increase of 8.28 points from IQ 4 to IQ 5 among 7 years old females from Punjab while the lowest surge was witnessed among 14 years old females from Chandigarh. In all, the highest increase from IQ 1 to IQ 5 was witnessed among 7 years old females from Punjab. Their IQ soared by 64.07 points after the intervention while the minimum overall increase in IQ was found to be 8.75 points among 12 years old females from Chandigarh. 
Table 6: Increase in mean value of FF of respondents in experiment group

\begin{tabular}{|c|c|c|c|c|c|c|c|c|c|c|c|c|}
\hline $\begin{array}{l}\text { Age } \\
\text { (Yrs) }\end{array}$ & \multicolumn{2}{|c|}{ Group } & FF1 & FF2 & FF3 & FF4 & FF5 & $\begin{array}{c}\text { FF2- } \\
\text { FF1 }\end{array}$ & $\begin{array}{c}\text { FF3- } \\
\text { FF2 }\end{array}$ & $\begin{array}{l}\text { FF4- } \\
\text { FF3 }\end{array}$ & $\begin{array}{c}\text { FF5- } \\
\text { FF4 }\end{array}$ & $\begin{array}{c}\text { FF5- } \\
\text { FF1 }\end{array}$ \\
\hline \multirow{4}{*}{7} & \multirow{2}{*}{ Male } & Chd & 74.22 & 78.48 & 82.74 & 90.05 & 94.57 & 4.26 & 4.26 & 7.30 & 4.52 & 20.34 \\
\hline & & $\mathrm{Pb}$ & 66.21 & 70.60 & $\begin{array}{l}74.99 \\
\end{array}$ & 82.25 & 86.55 & 4.39 & 4.39 & 7.25 & 4.30 & 20.33 \\
\hline & \multirow{2}{*}{ Female } & Chd & 90.85 & 96.34 & 101.83 & 111.00 & 117.59 & 5.48 & 5.49 & 9.17 & 6.59 & 26.74 \\
\hline & & $\mathrm{Pb}$ & 86.99 & 92.51 & 98.04 & 107.35 & 114.01 & 5.52 & 5.52 & 9.31 & 6.66 & 27.02 \\
\hline \multirow{4}{*}{8} & \multirow{2}{*}{ Male } & Chd & 72.09 & 79.37 & 86.65 & 94.89 & 99.70 & 7.28 & 7.28 & 8.23 & 4.82 & 27.62 \\
\hline & & $\mathrm{Pb}$ & 69.66 & 77.19 & 84.71 & 92.95 & 97.79 & 7.52 & 7.52 & 8.24 & 4.84 & 28.13 \\
\hline & \multirow{2}{*}{ Female } & Chd & 76.62 & 83.87 & 91.12 & 98.05 & 102.72 & 7.25 & 7.25 & 6.93 & 4.67 & 26.11 \\
\hline & & $\mathrm{Pb}$ & 72.97 & 80.26 & 87.55 & 94.76 & 99.49 & 7.29 & 7.29 & 7.22 & 4.72 & 26.52 \\
\hline \multirow{4}{*}{9} & \multirow{2}{*}{ Male } & Chd & 64.72 & 72.31 & 79.89 & 86.21 & 90.22 & 7.58 & 7.58 & 6.32 & 4.01 & 25.50 \\
\hline & & $\mathrm{Pb}$ & 67.65 & 75.19 & 82.72 & 90.01 & 94.18 & 7.54 & 7.54 & 7.29 & 4.16 & 26.53 \\
\hline & \multirow{2}{*}{ Female } & Chd & 66.46 & 74.42 & 82.38 & 88.86 & 92.88 & 7.96 & 7.96 & 6.48 & 4.02 & 26.42 \\
\hline & & $\mathrm{Pb}$ & 70.72 & 78.38 & 86.03 & 92.77 & 97.01 & 7.66 & 7.66 & 6.73 & 4.24 & 26.29 \\
\hline \multirow{4}{*}{10} & \multirow{2}{*}{ Male } & Chd & 65.36 & 69.25 & 73.30 & 78.31 & 81.79 & 3.89 & 4.05 & 5.02 & 3.47 & 16.42 \\
\hline & & $\mathrm{Pb}$ & 64.37 & 67.98 & 71.78 & 76.95 & 80.42 & 3.61 & 3.80 & 5.17 & 3.47 & 16.05 \\
\hline & \multirow{2}{*}{ Female } & Chd & 64.80 & 68.54 & 72.45 & 77.76 & 81.25 & 3.74 & 3.90 & 5.31 & 3.49 & 16.44 \\
\hline & & $\mathrm{Pb}$ & 64.15 & 67.74 & 71.52 & 76.95 & 80.44 & 3.59 & 3.77 & 5.43 & 3.49 & 16.29 \\
\hline \multirow{4}{*}{11} & \multirow{2}{*}{ Male } & Chd & 60.80 & 63.16 & 65.66 & 70.72 & 73.94 & 2.36 & 2.51 & 5.05 & 3.22 & 13.14 \\
\hline & & $\mathrm{Pb}$ & 61.13 & 62.86 & 64.72 & 69.95 & 73.18 & 1.74 & 1.86 & 5.22 & 3.24 & 12.06 \\
\hline & \multirow{2}{*}{ Female } & Chd & 55.23 & 57.32 & 59.54 & 63.61 & 66.47 & 2.09 & 2.22 & 4.06 & 2.86 & 11.24 \\
\hline & & $\mathrm{Pb}$ & 57.43 & 59.57 & 61.85 & 66.15 & 69.14 & 2.14 & 2.28 & 4.30 & 2.99 & 11.71 \\
\hline \multirow{4}{*}{12} & \multirow{2}{*}{ Male } & Chd & 53.93 & 54.68 & 55.45 & 56.40 & 57.49 & 0.75 & 0.77 & 0.94 & 1.09 & 3.56 \\
\hline & & $\mathrm{Pb}$ & 50.93 & 51.79 & 52.67 & 53.00 & 54.47 & 0.86 & 0.88 & 0.33 & 1.47 & 3.54 \\
\hline & \multirow{2}{*}{ Female } & Chd & 52.00 & 53.00 & 53.28 & 58.07 & 61.49 & 0.99 & 0.28 & 4.79 & 3.42 & 9.48 \\
\hline & & $\mathrm{Pb}$ & 53.00 & 54.00 & 54.07 & 59.25 & 62.93 & 1.01 & 0.07 & 5.18 & 3.69 & 9.94 \\
\hline \multirow{4}{*}{13} & \multirow{2}{*}{ Male } & Chd & 49.29 & 54.03 & 59.91 & 62.50 & 65.22 & 4.74 & 5.88 & 2.59 & 2.72 & 15.93 \\
\hline & & $\mathrm{Pb}$ & 47.99 & 52.76 & 58.67 & 61.16 & 63.82 & 4.77 & 5.92 & 2.49 & 2.66 & 15.83 \\
\hline & \multirow{2}{*}{ Female } & Chd & 50.06 & 55.06 & 61.09 & 64.41 & 67.24 & 5.00 & 6.03 & 3.31 & 2.84 & 17.18 \\
\hline & & $\mathrm{Pb}$ & 51.90 & 57.39 & 63.94 & 67.59 & 70.57 & 5.49 & 6.55 & 3.65 & 2.98 & 18.67 \\
\hline & & Chd & 51.21 & 55.88 & 60.97 & 64.23 & 67.05 & 4.67 & 5.10 & 3.25 & 2.82 & 15.84 \\
\hline 14 & Mrate & $\mathrm{Pb}$ & 50.97 & 55.62 & 60.69 & 64.00 & 66.82 & 4.65 & 5.07 & 3.31 & 2.82 & 15.85 \\
\hline 14 & $F_{0}$ & Chd & 48.66 & 53.10 & 57.94 & 60.71 & 63.34 & 4.44 & 4.84 & 2.77 & 2.63 & 14.68 \\
\hline & & $\mathrm{Pb}$ & 47.12 & 51.41 & 56.10 & 59.07 & 61.67 & 4.30 & 4.69 & 2.97 & 2.60 & 14.55 \\
\hline & & Chd & 47.72 & 51.57 & 55.74 & 58.94 & 61.56 & 3.85 & 4.16 & 3.20 & 2.62 & 13.84 \\
\hline 15 & Miare & $\mathrm{Pb}$ & 49.35 & 53.32 & 57.62 & 61.38 & 64.12 & 3.98 & 4.30 & 3.75 & 2.74 & 14.77 \\
\hline 10 & $F_{0}$ & Chd & 42.91 & 45.72 & 48.74 & 52.90 & 55.61 & 2.82 & 3.02 & 4.15 & 2.71 & 12.70 \\
\hline & Tente & $\mathrm{Pb}$ & 44.74 & 47.61 & 50.69 & 55.36 & 58.28 & 2.88 & 3.08 & 4.67 & 2.92 & 13.54 \\
\hline & & Chd & 46.36 & 48.72 & 51.21 & 55.24 & 57.93 & 2.36 & 2.48 & 4.03 & 2.70 & 11.57 \\
\hline & & $\mathrm{Pb}$ & 42.97 & 45.17 & 47.47 & 51.32 & 53.85 & 2.19 & 2.30 & 3.85 & 2.53 & 10.88 \\
\hline 10 & & Chd & 48.01 & 50.46 & 53.04 & 56.66 & 59.31 & 2.45 & 2.57 & 3.62 & 2.65 & 11.29 \\
\hline & 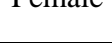 & $\mathrm{Pb}$ & 49.62 & 52.15 & 54.81 & 58.62 & 61.35 & 2.53 & 2.66 & 3.81 & 2.73 & 11.73 \\
\hline
\end{tabular}

When the difference in subsequent FF was reported, it was notified that there was maximum increase of 7.69 points from FF 1 to FF 2 and from FF 2 to FF 3 among 9 years old females from Chandigarh while the lowest surge was witnessed among 12 years old males from Chandigarh from FF 1 to FF 2 whereas 
in case of from FF 2 to FF 3, the least increase was noticed among 12 years old females from Punjab. The FF 4 was found to be 9.31 points higher than the previous among 7 years old females from Punjab while the least change was an increase by 0.33 points in case of 12 years old males from Punjab. There was maximum increase of 6.66 points from FF 4 to FF 5 among 7 years old females from Chandigarh while the lowest surge was witnessed among 12 years old males from Chandigarh. In all, the highest increase from FF 1 to FF 5 was witnessed among 8 years old males from Punjab. Their FF soared by 28.13 points after the intervention while the minimum overall increase in FF was found to be 3.54 points among 12 years old males from Punjab.

Table 7: Increase in mean value of DMA of respondents in experiment group

\begin{tabular}{|c|c|c|c|c|c|c|c|c|c|c|c|c|}
\hline $\begin{array}{l}\text { Age } \\
\text { (Yrs) }\end{array}$ & \multicolumn{2}{|c|}{ Group } & DMA1 & DMA2 & DMA3 & DMA4 & DMA5 & DMA2- & DMA3- & DMA4- & $\begin{array}{l}\text { DMA5- } \\
\text { DMA4 }\end{array}$ & $\begin{array}{l}\text { DMA5- } \\
\text { DMA1 }\end{array}$ \\
\hline \multirow{4}{*}{7} & \multirow{2}{*}{ Male } & Chd & 0.38 & 0.61 & 0.71 & 0.77 & 0.81 & 0.24 & 0.10 & 0.06 & 0.04 & 0.43 \\
\hline & & $\mathrm{Pb}$ & 0.34 & 0.55 & 0.64 & 0.70 & 0.74 & 0.21 & 0.09 & 0.06 & 0.04 & 0.40 \\
\hline & \multirow{2}{*}{ Female } & Chd & 0.49 & 0.78 & 0.92 & 1.00 & 1.06 & 0.29 & 0.15 & 0.08 & 0.06 & 0.58 \\
\hline & & $\mathrm{Pb}$ & 0.46 & 0.73 & 0.88 & 0.97 & 1.03 & 0.28 & 0.15 & 0.08 & 0.06 & 0.57 \\
\hline \multirow{4}{*}{8} & \multirow{2}{*}{ Male } & Chd & 0.36 & 0.59 & 0.67 & 0.73 & 0.77 & 0.23 & 0.08 & 0.06 & 0.04 & 0.41 \\
\hline & & $\mathrm{Pb}$ & 0.35 & 0.57 & 0.66 & 0.72 & 0.76 & 0.22 & 0.08 & 0.06 & 0.04 & 0.41 \\
\hline & \multirow{2}{*}{ Female } & Chd & 0.39 & 0.64 & 0.72 & 0.77 & 0.80 & 0.24 & 0.08 & 0.05 & 0.04 & 0.41 \\
\hline & & $\mathrm{Pb}$ & 0.38 & 0.61 & 0.70 & 0.75 & 0.79 & 0.24 & 0.08 & 0.05 & 0.04 & 0.42 \\
\hline \multirow{4}{*}{9} & \multirow{2}{*}{ Male } & Chd & 0.32 & 0.52 & 0.59 & 0.63 & 0.66 & 0.20 & 0.06 & 0.05 & 0.03 & 0.34 \\
\hline & & $\mathrm{Pb}$ & 0.34 & 0.55 & 0.62 & 0.67 & 0.70 & 0.22 & 0.07 & 0.05 & 0.03 & 0.37 \\
\hline & \multirow{2}{*}{ Female } & Chd & 0.33 & 0.53 & 0.60 & 0.64 & 0.67 & 0.21 & 0.06 & 0.05 & 0.03 & 0.34 \\
\hline & & $\mathrm{Pb}$ & 0.35 & 0.58 & 0.65 & 0.70 & 0.73 & 0.23 & 0.07 & 0.05 & 0.03 & 0.37 \\
\hline \multirow{4}{*}{10} & \multirow{2}{*}{ Male } & Chd & 0.32 & 0.52 & 0.58 & 0.62 & 0.64 & 0.20 & 0.06 & 0.04 & 0.03 & 0.32 \\
\hline & & $\mathrm{Pb}$ & 0.32 & 0.52 & 0.58 & 0.62 & 0.65 & 0.20 & 0.06 & 0.04 & 0.03 & 0.33 \\
\hline & \multirow{2}{*}{ Female } & Chd & 0.32 & 0.52 & 0.58 & 0.62 & 0.64 & 0.20 & 0.06 & 0.04 & 0.03 & 0.33 \\
\hline & & $\mathrm{Pb}$ & 0.32 & 0.52 & 0.58 & 0.62 & 0.65 & 0.20 & 0.06 & 0.04 & 0.03 & 0.33 \\
\hline \multirow{4}{*}{11} & \multirow{2}{*}{ Male } & Chd & 0.29 & 0.48 & 0.54 & 0.58 & 0.61 & 0.19 & 0.06 & 0.04 & 0.03 & 0.31 \\
\hline & & $\mathrm{Pb}$ & 0.30 & 0.49 & 0.55 & 0.60 & 0.62 & 0.20 & 0.06 & 0.04 & 0.03 & 0.32 \\
\hline & \multirow{2}{*}{ Female } & Chd & 0.26 & 0.43 & 0.48 & 0.51 & 0.54 & 0.17 & 0.05 & 0.03 & 0.02 & 0.27 \\
\hline & & $\mathrm{Pb}$ & 0.28 & 0.45 & 0.50 & 0.54 & 0.56 & 0.18 & 0.05 & 0.03 & 0.02 & 0.28 \\
\hline \multirow{4}{*}{12} & \multirow{2}{*}{ Male } & Chd & 0.26 & 0.42 & 0.47 & 0.49 & 0.51 & 0.16 & 0.05 & 0.02 & 0.02 & 0.25 \\
\hline & & $\mathrm{Pb}$ & 0.24 & 0.40 & 0.44 & 0.47 & 0.49 & 0.15 & 0.05 & 0.02 & 0.02 & 0.25 \\
\hline & \multirow{2}{*}{ Female } & Chd & 0.28 & 0.45 & 0.53 & 0.58 & 0.61 & 0.17 & 0.08 & 0.05 & 0.03 & 0.33 \\
\hline & & $\mathrm{Pb}$ & 0.28 & 0.45 & 0.54 & 0.60 & 0.63 & 0.17 & 0.09 & 0.05 & 0.04 & 0.35 \\
\hline \multirow{4}{*}{13} & \multirow{2}{*}{ Male } & Chd & 0.23 & 0.37 & 0.42 & 0.43 & 0.45 & 0.14 & 0.04 & 0.01 & 0.02 & 0.22 \\
\hline & & $\mathrm{Pb}$ & 0.22 & 0.36 & 0.40 & 0.42 & 0.43 & 0.14 & 0.04 & 0.01 & 0.02 & 0.21 \\
\hline & \multirow{2}{*}{ Female } & Chd & 0.24 & 0.38 & 0.43 & 0.45 & 0.47 & 0.15 & 0.04 & 0.02 & 0.02 & 0.23 \\
\hline & & $\mathrm{Pb}$ & 0.25 & 0.40 & 0.45 & 0.47 & 0.49 & 0.16 & 0.05 & 0.02 & 0.02 & 0.25 \\
\hline \multirow{4}{*}{14} & \multirow{2}{*}{ Male } & Chd & 0.24 & 0.39 & 0.44 & 0.45 & 0.48 & 0.15 & 0.04 & 0.02 & 0.02 & 0.23 \\
\hline & & $\mathrm{Pb}$ & 0.24 & 0.39 & 0.43 & 0.45 & 0.47 & 0.15 & 0.04 & 0.02 & 0.02 & 0.23 \\
\hline & Female & Chd & 0.23 & 0.37 & 0.42 & 0.43 & 0.45 & 0.14 & 0.04 & 0.01 & 0.02 & 0.22 \\
\hline & remale & $\mathrm{Pb}$ & 0.22 & 0.36 & 0.40 & 0.42 & 0.44 & 0.14 & 0.04 & 0.02 & 0.02 & 0.22 \\
\hline & Male & Chd & 0.22 & 0.37 & 0.41 & 0.43 & 0.45 & 0.14 & 0.04 & 0.02 & 0.02 & 0.22 \\
\hline 15 & ivale & $\mathrm{Pb}$ & 0.23 & 0.38 & 0.42 & 0.45 & 0.47 & 0.15 & 0.04 & 0.03 & 0.02 & 0.24 \\
\hline $1 J$ & $\mathrm{~F}_{\mathrm{f}}$ & Chd & 0.20 & 0.32 & 0.37 & 0.40 & 0.42 & 0.13 & 0.05 & 0.03 & 0.02 & 0.23 \\
\hline & Thinat & $\mathrm{Pb}$ & 0.21 & 0.34 & 0.39 & 0.43 & 0.45 & 0.13 & 0.05 & 0.04 & 0.02 & 0.25 \\
\hline
\end{tabular}




\begin{tabular}{|l|c|c|c|c|c|c|c|c|c|c|c|c|}
\hline \multirow{4}{*}{16} & \multirow{2}{*}{ Male } & Chd & 0.22 & 0.35 & 0.40 & 0.43 & 0.45 & 0.14 & 0.05 & 0.03 & 0.02 & 0.23 \\
\cline { 3 - 13 } & \multirow{2}{*}{ Female } & $\mathrm{Pb}$ & 0.20 & 0.32 & 0.36 & 0.39 & 0.41 & 0.12 & 0.04 & 0.03 & 0.02 & 0.22 \\
\cline { 3 - 14 } & & $\mathrm{Pb}$ & 0.23 & 0.37 & 0.42 & 0.44 & 0.46 & 0.14 & 0.05 & 0.03 & 0.02 & 0.24 \\
\hline
\end{tabular}

When the difference in DMA of respondents was reported, it was notified that there was maximum increase of 0.29 points from DMA 1 to DMA 2 among 7 years old females from Chandigarh whereas minimum increase was recorded among 16 years old males from Punjab. The highest change in the DMA was found to be $0.15,0.08$ and 0.06 points in third, fourth and fifth test among 7 years old females from Chandigarh and Punjab whereas the lowest change was notified among 13, 14 and 15 year old respondents. Overall, the highest increase from DMA 1 to DMA 5 was witnessed among 7 years old females from Chandigarh. Their DMA soared by 0.58 points after the intervention while the minimum overall increase in DMA was found to be 0.21 points among 13 years old males from Punjab. 
Table 8: Increase in mean value of CQ of respondents in experiment group

\begin{tabular}{|c|c|c|c|c|c|c|c|c|c|c|c|c|}
\hline Age (Yrs) & \multicolumn{2}{|l|}{ Group } & CQ1 & CQ2 & CQ3 & CQ4 & CQ5 & $\begin{array}{l}\text { CQ2- } \\
\text { CQ1 }\end{array}$ & $\begin{array}{l}\text { CQ3- } \\
\text { CQ2 }\end{array}$ & $\begin{array}{l}\text { CQ4- } \\
\text { CQ3 }\end{array}$ & $\begin{array}{l}\text { CQ5- } \\
\text { CQ4 }\end{array}$ & $\begin{array}{l}\text { CQ5- } \\
\text { CQ1 }\end{array}$ \\
\hline \multirow[t]{4}{*}{7} & \multirow[t]{2}{*}{ Male } & Chd & 0.56 & 0.69 & 0.73 & 0.77 & 0.85 & 0.12 & 0.04 & 0.04 & 0.08 & 0.29 \\
\hline & & $\mathrm{Pb}$ & 0.57 & 0.69 & 0.73 & 0.77 & 0.85 & 0.12 & 0.04 & 0.04 & 0.08 & 0.29 \\
\hline & \multirow[t]{2}{*}{ Female } & Chd & 0.55 & 0.66 & 0.70 & 0.74 & 0.82 & 0.12 & 0.04 & 0.04 & 0.08 & 0.27 \\
\hline & & $\mathrm{Pb}$ & 0.55 & 0.67 & 0.71 & 0.75 & 0.83 & 0.12 & 0.04 & 0.04 & 0.08 & 0.28 \\
\hline \multirow[t]{4}{*}{8} & \multirow[t]{2}{*}{ Male } & Chd & 0.52 & 0.63 & 0.67 & 0.71 & 0.78 & 0.11 & 0.04 & 0.04 & 0.07 & 0.26 \\
\hline & & $\mathrm{Pb}$ & 0.54 & 0.66 & 0.70 & 0.74 & 0.82 & 0.12 & 0.04 & 0.04 & 0.08 & 0.27 \\
\hline & \multirow[t]{2}{*}{ Female } & Chd & 0.54 & 0.66 & 0.70 & 0.74 & 0.81 & 0.12 & 0.04 & 0.04 & 0.08 & 0.27 \\
\hline & & $\mathrm{Pb}$ & 0.55 & 0.67 & 0.72 & 0.76 & 0.84 & 0.12 & 0.04 & 0.04 & 0.08 & 0.28 \\
\hline \multirow[t]{4}{*}{9} & \multirow[t]{2}{*}{ Male } & Chd & 0.54 & 0.66 & 0.70 & 0.74 & 0.83 & 0.12 & 0.04 & 0.04 & 0.09 & 0.28 \\
\hline & & $\mathrm{Pb}$ & 0.57 & 0.70 & 0.74 & 0.78 & 0.87 & 0.12 & 0.04 & 0.04 & 0.09 & 0.30 \\
\hline & \multirow[t]{2}{*}{ Female } & Chd & 0.54 & 0.66 & 0.70 & 0.74 & 0.83 & 0.12 & 0.04 & 0.04 & 0.09 & 0.28 \\
\hline & & $\mathrm{Pb}$ & 0.53 & 0.65 & 0.69 & 0.73 & 0.81 & 0.12 & 0.04 & 0.04 & 0.09 & 0.28 \\
\hline \multirow[t]{4}{*}{10} & \multirow[t]{2}{*}{ Male } & Chd & 0.52 & 0.63 & 0.67 & 0.71 & 0.79 & 0.11 & 0.04 & 0.04 & 0.08 & 0.27 \\
\hline & & $\mathrm{Pb}$ & 0.53 & 0.64 & 0.68 & 0.72 & 0.80 & 0.12 & 0.04 & 0.04 & 0.08 & 0.27 \\
\hline & \multirow[t]{2}{*}{ Female } & Chd & 0.51 & 0.62 & 0.66 & 0.69 & 0.76 & 0.11 & 0.04 & 0.04 & 0.07 & 0.26 \\
\hline & & $\mathrm{Pb}$ & 0.51 & 0.62 & 0.66 & 0.70 & 0.77 & 0.11 & 0.04 & 0.04 & 0.07 & 0.26 \\
\hline \multirow[t]{4}{*}{11} & \multirow[t]{2}{*}{ Male } & Chd & 0.56 & 0.68 & 0.72 & 0.76 & 0.83 & 0.12 & 0.04 & 0.04 & 0.07 & 0.27 \\
\hline & & $\mathrm{Pb}$ & 0.56 & 0.68 & 0.72 & 0.76 & 0.84 & 0.12 & 0.04 & 0.04 & 0.07 & 0.27 \\
\hline & \multirow[t]{2}{*}{ Female } & Chd & 0.55 & 0.67 & 0.71 & 0.75 & 0.83 & 0.12 & 0.04 & 0.04 & 0.07 & 0.27 \\
\hline & & $\mathrm{Pb}$ & 0.56 & 0.68 & 0.72 & 0.77 & 0.84 & 0.12 & 0.04 & 0.04 & 0.07 & 0.28 \\
\hline \multirow[t]{4}{*}{12} & \multirow[t]{2}{*}{ Male } & Chd & 0.53 & 0.64 & 0.68 & 0.72 & 0.79 & 0.11 & 0.04 & 0.04 & 0.07 & 0.26 \\
\hline & & $\mathrm{Pb}$ & 0.54 & 0.66 & 0.70 & 0.74 & 0.81 & 0.12 & 0.04 & 0.04 & 0.07 & 0.27 \\
\hline & \multirow[t]{2}{*}{ Female } & Chd & 0.57 & 0.69 & 0.73 & 0.78 & 0.85 & 0.12 & 0.04 & 0.04 & 0.07 & 0.28 \\
\hline & & $\mathrm{Pb}$ & 0.58 & 0.70 & 0.75 & 0.79 & 0.86 & 0.13 & 0.04 & 0.04 & 0.07 & 0.28 \\
\hline \multirow[t]{4}{*}{13} & \multirow[t]{2}{*}{ Male } & Chd & 0.54 & 0.66 & 0.70 & 0.74 & 0.80 & 0.12 & 0.04 & 0.04 & 0.07 & 0.26 \\
\hline & & $\mathrm{Pb}$ & 0.54 & 0.65 & 0.69 & 0.73 & 0.80 & 0.12 & 0.04 & 0.04 & 0.07 & 0.26 \\
\hline & \multirow[t]{2}{*}{ Female } & Chd & 0.57 & 0.69 & 0.73 & 0.77 & 0.84 & 0.12 & 0.04 & 0.04 & 0.07 & 0.28 \\
\hline & & $\mathrm{Pb}$ & 0.54 & 0.65 & 0.69 & 0.73 & 0.80 & 0.12 & 0.04 & 0.04 & 0.07 & 0.26 \\
\hline 14 & Male & Chd & 0.54 & 0.66 & 0.70 & 0.74 & 0.81 & 0.12 & 0.04 & 0.04 & 0.07 & 0.27 \\
\hline & & $\mathrm{Pb}$ & 0.53 & 0.65 & 0.68 & 0.72 & 0.79 & 0.12 & 0.04 & 0.04 & 0.07 & 0.26 \\
\hline & Female & Chd & 0.51 & 0.61 & 0.65 & 0.69 & 0.75 & 0.11 & 0.04 & 0.04 & 0.06 & 0.25 \\
\hline & & $\mathrm{Pb}$ & 0.54 & 0.66 & 0.70 & 0.74 & 0.81 & 0.12 & 0.04 & 0.04 & 0.07 & 0.27 \\
\hline 15 & Male & Chd & 0.57 & 0.70 & 0.74 & 0.78 & 0.86 & 0.12 & 0.04 & 0.04 & 0.07 & 0.28 \\
\hline & & $\mathrm{Pb}$ & 0.56 & 0.68 & 0.73 & 0.77 & 0.84 & 0.12 & 0.04 & 0.04 & 0.07 & 0.28 \\
\hline & Female & Chd & 0.55 & 0.66 & 0.70 & 0.74 & 0.81 & 0.12 & 0.04 & 0.04 & 0.07 & 0.27 \\
\hline & & $\mathrm{Pb}$ & 0.55 & 0.67 & 0.71 & 0.76 & 0.83 & 0.12 & 0.04 & 0.04 & 0.07 & 0.27 \\
\hline 16 & Male & Chd & 0.52 & 0.64 & 0.67 & 0.71 & 0.78 & 0.11 & 0.04 & 0.04 & 0.07 & 0.26 \\
\hline & & $\mathrm{Pb}$ & 0.55 & 0.67 & 0.71 & 0.75 & 0.82 & 0.12 & 0.04 & 0.04 & 0.07 & 0.27 \\
\hline & Female & Chd & 0.56 & 0.67 & 0.72 & 0.76 & 0.83 & 0.12 & 0.04 & 0.04 & 0.07 & 0.27 \\
\hline & & $\mathrm{Pb}$ & 0.55 & 0.67 & 0.71 & 0.76 & 0.83 & 0.12 & 0.04 & 0.04 & 0.07 & 0.27 \\
\hline
\end{tabular}

The highest mean value of CQ 1 was reported to be 0.58 among 12 years old females from Punjab whereas the least was found among 10 years old females from Chandigarh and Punjab as well as 14 years old females from Chandigarh. CQ 2 was found to be maximum among 9 years old males from 
Punjab, 12 years old females from Punjab and 15 years old males from Chandigarh while the minimum was recorded among 14 years old females from Chandigarh. CQ 3 and CQ 4 were maximum among 12 years old females from Punjab. CQ 5 was highest among 9 years old males from Punjab. However, the minimum CQ in last three tests was reported among 14 years old females from Chandigarh. When the difference in subsequent CQ was reported, it was notified that there was maximum increase of 0.13 points from CQ 1 to CQ 2 among 12 years old females from Punjab while the lowest surge was witnessed among 10 year old females from Chandigarh and Punjab. The CQ rose by 0.04 points among all respondents in the next two tests. There was maximum increase of 0.09 points from CQ 4 to CQ 5 among 9 years old respondents while the lowest surge was witnessed among 14 years old females from Chandigarh.

Table 9: Increase in mean value of marks of respondents in experiment group

\begin{tabular}{|c|c|c|c|c|c|}
\hline Age (Yrs) & \multicolumn{2}{|c|}{ Group } & M1 & M2 & M2-M1 \\
\hline \multirow{4}{*}{7} & \multirow{2}{*}{ Male } & Chd & 56.37 & 65.73 & 9.35 \\
\hline & & $\mathrm{Pb}$ & 50.8 & 60.24 & 9.44 \\
\hline & \multirow{2}{*}{ Female } & Chd & 59.62 & 68.94 & 9.32 \\
\hline & & $\mathrm{Pb}$ & 58.79 & 69.62 & 10.84 \\
\hline \multirow{4}{*}{8} & \multirow{2}{*}{ Male } & Chd & 58.3 & 66.28 & 7.98 \\
\hline & & $\mathrm{Pb}$ & 56.47 & 65.59 & 9.12 \\
\hline & \multirow{2}{*}{ Female } & Chd & 57.3 & 64.64 & 7.34 \\
\hline & & $\mathrm{Pb}$ & 58.79 & 69.63 & 10.84 \\
\hline \multirow{4}{*}{9} & \multirow{2}{*}{ Male } & Chd & 56.83 & 61.52 & 4.69 \\
\hline & & $\mathrm{Pb}$ & 58.47 & 64.63 & 6.16 \\
\hline & \multirow{2}{*}{ Female } & Chd & 58.66 & 64.11 & 5.45 \\
\hline & & $\mathrm{Pb}$ & 58.79 & 69.63 & 10.84 \\
\hline \multirow{4}{*}{10} & \multirow{2}{*}{ Male } & Chd & 58.56 & 63.01 & 4.45 \\
\hline & & $\mathrm{Pb}$ & 57.89 & 61.86 & 3.98 \\
\hline & \multirow{2}{*}{ Female } & Chd & 58.4 & 63.48 & 5.08 \\
\hline & & $\mathrm{Pb}$ & 58.79 & 69.62 & 10.83 \\
\hline \multirow{4}{*}{11} & \multirow{2}{*}{ Male } & Chd & 58.86 & 65.1 & 6.24 \\
\hline & & $\mathrm{Pb}$ & 56.64 & 62.71 & 6.07 \\
\hline & \multirow{2}{*}{ Female } & Chd & 55.28 & 60.61 & 5.33 \\
\hline & & $\mathrm{Pb}$ & 58.79 & 69.62 & 10.84 \\
\hline \multirow{4}{*}{12} & \multirow{2}{*}{ Male } & Chd & 57.24 & 64.41 & 7.17 \\
\hline & & $\mathrm{Pb}$ & 56.19 & 63.8 & 7.61 \\
\hline & \multirow{2}{*}{ Female } & Chd & 48.88 & 58.57 & 9.7 \\
\hline & & $\mathrm{Pb}$ & 58.79 & 69.62 & 10.83 \\
\hline \multirow{2}{*}{13} & \multirow{2}{*}{ Male } & Chd & 55.96 & 60.24 & 4.27 \\
\hline & & $\mathrm{Pb}$ & 55.34 & 59.52 & 4.18 \\
\hline
\end{tabular}




\begin{tabular}{|c|c|c|c|c|c|}
\hline \multirow{3}{*}{14} & \multirow{3}{*}{ Female } & $\mathrm{Chd}$ & 56.29 & 60.41 & 4.12 \\
\cline { 3 - 6 } & & $\mathrm{Pb}$ & 58.79 & 69.63 & 10.84 \\
\hline \multirow{3}{*}{ Male } & $\mathrm{Chd}$ & 57.51 & 62.16 & 4.65 \\
\cline { 3 - 6 } & & $\mathrm{Pb}$ & 58.4 & 63.6 & 5.2 \\
\cline { 3 - 6 } & \multirow{3}{*}{ Female } & $\mathrm{Chd}$ & 53.81 & 57.37 & 3.57 \\
\cline { 3 - 6 } & & $\mathrm{Pb}$ & 58.79 & 69.62 & 10.84 \\
\hline \multirow{3}{*}{15} & \multirow{3}{*}{ Male } & $\mathrm{Chd}$ & 55.01 & 56.72 & 1.71 \\
\cline { 3 - 6 } & & $\mathrm{Pb}$ & 56.64 & 58.61 & 1.98 \\
\cline { 3 - 6 } & \multirow{3}{*}{ Female } & $\mathrm{Chd}$ & 55.37 & 64.78 & 9.42 \\
\cline { 3 - 6 } & & $\mathrm{Pb}$ & 58.79 & 69.62 & 10.84 \\
\hline \multirow{3}{*}{16} & \multirow{3}{*}{ Male } & $\mathrm{Chd}$ & 57.48 & 62.89 & 5.41 \\
\cline { 3 - 6 } & & $\mathrm{Pb}$ & 56.87 & 63.22 & 6.35 \\
\cline { 3 - 6 } & \multirow{3}{*}{ Female } & $\mathrm{Chd}$ & 56.38 & 62.2 & 5.81 \\
\cline { 3 - 6 } & & $\mathrm{Pb}$ & 58.79 & 69.63 & 10.84 \\
\hline
\end{tabular}

The highest mean value of M1 was reported as 59.62 among 7 years old females from Chandigarh while it was minimum i.e. 48.88 among 12 years old females from Chandigarh. After intervention, the maximum value was 69.63 among 8,9,13 and 16 years old females from Punjab. The minimum value of M2 was found to be 56.72 among 15 years old males from Chandigarh.

\section{Conclusion}

In conclusion, it was found that the highest IQ was reported among 7 year old females from Chandigarh in all the tests. The minimum IQ 1 was found among 7 years old females from Punjab while in all subsequent tests, it was found minimum among 12 years old females from Chandigarh. The highest FF was reported among 7 year old females from Chandigarh in all the tests. The minimum FF 1 and was found among 15 years old females from Chandigarh while in all subsequent tests, it was found minimum among 16 years old males from Punjab. The highest DMA was reported among 7 years old females from Chandigarh in all the tests. The minimum DMA in first three tests was found among 16 years old males from Punjab. However, 15 years old females from Chandigarh were also found to have the lowest DMA in test 1 and test 2. The highest mean value of CQ 1 was reported to be 0.58 among 12 years old females from Punjab whereas the least was found among 10 years old females from Chandigarh and Punjab as well as 14 years old females from Chandigarh. In all, the highest increase from CQ 1 to CQ 5 was witnessed among 9 years old males from Punjab. Their CQ soared by 0.3 points after the intervention while the minimum overall increase in CQ was found to be 0.25 points among 14 years old females from Chandigarh. Overall, the highest increase of 10.84 points was witnessed among female respondents in Punjab aged 7, 8, 9, 11, 13, 14, 15 and 16 years. The least increase of 1.71 points was witnessed among 15 years old males from Chandigarh. The study found vibrant increase in the cognitive abilities and academic achievement of students. No such significant change could be traced in control group. Similar findings have been reported by Sternberg and Sternberg (2016), Stronge (2018), Temur (2007), Tessier (2018), Thiele (2003), Thurstone (1938), Torrance (1977), Tudge and Winterhoff (1993), Vartanian (2009), Vernon (1950), Viljaranta et al. (2014) and Wajiha (2002). 


\section{References}

Abdallah, M. M. S. (2008). Multiple Ways to be Smart: Gardener's Theory of Multiple Intelligences and its Educational Implications in English Teaching and Oral Communication. Online Submission.

Acharya, A., D. Pal, and, S. Sengupta. 2015. Educational Achievement and Self-Esteem of College Students: A Comparative Study Between The Tribal And Non-Tribal Girl Students Of Agartala. International Journal of Innovative Research and Studies. 14(7).

Bala, I., Kaur, R., \& Singh, S. (2017). Decision-making styles and academic achievement. DecisionMaking, 2(4).

Das, J. P., Kirby, J. R., \& Jarman, R. F. (2013). Simultaneous and successive cognitive processes. Academic Press.

Deshmukh, K. P. M. (2015). Comparison of self-concept of school children belonging to high \& low fitness groups. Scientific Committee Members, 275.

Diseth, A. (2003). Personality and approaches to learning as predictors of academic achievement. European Journal of Personality, 17(2), 143-155.

Donnelly, J. E., Hillman, C. H., Castelli, D., Etnier, J. L., Lee, S., Tomporowski, P., ... \& Szabo-Reed, A. N. (2016). Physical activity, fitness, cognitive function, and academic achievement in children: a systematic review. Medicine and Science in Sports and Exercise, 48(6), 1197.

Dung, N. T., \& Tuan, L. T. (2011). Accommodating classroom activities to EFL learners' multiple intelligences. Mediterranean Journal of Social Sciences, 2(1), 79-109.

Janssen, M., Chinapaw, M. J. M., Rauh, S. P., Toussaint, H. M., Van Mechelen, W., \& Verhagen, E. A. L. M. (2014). A short physical activity break from cognitive tasks increases selective attention in primary school children aged 10-11. Mental Health and Physical Activity, 7(3), 129-134.

McFarlane, D. A. (2011). Multiple Intelligences: The Most Effective Platform for Global 21st Century Educational and Instructional Methodologies. College Quarterly, 14(2), n2.

Nuthana, P. G. (2007). Gender analysis of academic achievement among high school students (Doctoral dissertation, UAS, Dharwad).

Saeidi, M. (2009). The implementation of multiple intelligences theory in the classroom: Different ways of learning and teaching.

Soares, D. L., Lemos, G. C., Primi, R., \& Almeida, L. S. (2015). The relationship between intelligence and academic achievement throughout middle school: The role of students' prior academic performance. Learning and Individual Differences, 41, 73-78.

Sternberg, R. J., \& Sternberg, K. (2016). Cognitive psychology. Nelson Education.

Stronge, J. H. (2018). Qualities of effective teachers. ASCD.

Teele, S. (2004). Overcoming barricades to reading: A multiple intelligences approach. Corwin Press.

Temur, O. D. (2007). The Effects of Teaching Activities Prepared According to the Multiple Intelligence Theory on Mathematics Achievements and Permanence of Information Learned by 4th Grade Students. International Journal of Environmental and Science Education, 2(4), 86-91.

Tessier, R. (2018). The Relationship among Creativity, Priming, Cognitive Control, and Interpersonal Intelligence Expression (Doctoral dissertation, Hofstra University).

Thiele, J. E. (2003). Learning patterns of online students. Journal of Nursing Education, 42(8), 364-366.

Thurstone, L. L. (1938). Primary mental abilities.

Torrance, E. P. (1977). Creativity in the Classroom; What Research Says to the Teacher.

Tudge, J. R., \& Winterhoff, P. A. (1993). Vygotsky, Piaget, and Bandura: Perspectives on the relations between the social world and cognitive development. Human Development, 36(2), 61-81.

Vartanian, O. (2009). Variable attention facilitates creative problem solving. Psychology of Aesthetics, Creativity, and the Arts, 3(1), 57.

Vernon, P. E. (1950). The hierarchy ability. Intelligence and Ability, 179-192. 
Viljaranta, J., Tolvanen, A., Aunola, K., \& Nurmi, J. E. (2014). The developmental dynamics between interest, self-concept of ability, and academic performance. Scandinavian Journal of Educational Research, 58(6), 734-756.

Wajiha, A. H. (2002). Factors affecting academic achievement of IX standard students in mathematics. Willingham, D. T. (2004). Reframing the mind. Education Next, 4(3).

Zabelina, D. L., \& Robinson, M. D. (2010). Creativity as flexible cognitive control. Psychology of Aesthetics, Creativity, and the Arts, 4(3), 136. 